Article

\title{
The Innovation Function of Hybridization in Public Relations
}

\author{
Olaf Hoffjann \\ Department of Communication Studies, University of Bamberg, Germany; E-Mail: olaf.hoffjann@uni-bamberg.de
}

Submitted: 4 January 2021 | Accepted: 15 March 2021 | Published: 5 August 2021

\begin{abstract}
From content marketing and corporate publishing to storytelling and brand PR-the literature contains many examples of hybrid structures in strategic communication in general and more specifically in public relations (PR). The question that arises is which problem these hybrid structures solve. This article focuses on a systems theoretical basis on the function of these hybrid structures. Hybridization is understood as a process by which a social system adopts program structures of another system. Hybridization as a strategy assumes an innovation function in systems and facilitates learning. Hybridizations can be observed in PR on two logical levels: Firstly, PR is itself the result of a hybridization process. This is an example of how differentiated systems can originate from hybrid structures. Secondly, like every form of strategic communication, PR suffers from a lack of trustworthiness, attention and relevance of its communication objects. In order to be able to continue to influence decisions in the interest of those described positively, PR unscrupulously adopts structures of journalism, advertising and entertainment.
\end{abstract}

\section{Keywords}

advertising; entertainment; hybridization; public relations; public sphere; strategic communication; systems theory

\section{Issue}

This article is part of the issue "Complexity, Hybridity, Liminality: Challenges of Researching Contemporary Promotional Cultures" edited by lan Somerville (University of Leicester, UK) and Lee Edwards (London School of Economics and Political Science, UK).

(C) 2021 by the author; licensee Cogitatio (Lisbon, Portugal). This article is licensed under a Creative Commons Attribution 4.0 International License (CC BY).

\section{Introduction}

In recent years, hybrid structures in strategic communication have been described many times (e.g., Mangold \& Faulds, 2009; Taiminen et al., 2015). While the respective advantages and opportunities offered by practices such as content marketing, corporate publishing, storytelling or brand PR have been described, there is still no convincing answer to the question: What problem do hybridization processes solve in general and in strategic communication and public relations (PR) specifically? This is the question of the function of hybridization and hybrid structures. This question will be answered in the article using PR as an example.

The theoretical basis of the contribution is systems theory (Luhmann, 1995; Schoeneborn, 2011). The central assumption of systems theory is the operative unity of social systems. Systems do not mix in hybridizations, but one system adopts structures of the other system. To be more precise: Hybridization is understood as a process in which a social system adopts program structures of an environmental system, i.e., a system in the environment (Görke, 2009). Hybridization as a strategy thus assumes an innovation function in systems and enables learning. Hybridizations can be described in PR on two logical levels: Firstly, PR is itself the result of a hybridization process (Section 4). This is an example of how differentiated systems can originate from hybrid structures. Secondly, like every form of strategic communication, PR suffers from a lack of trustworthiness, attention and relevance among its communication objects. In order to be able to continue to influence decisions in the interest of those described positively, PR unscrupulously adopts structures of journalism, advertising and entertainment (Section 5). Examples of such hybrid structures include content marketing, brand journalism, storytelling or campaigning. In this article, a systemic perspective is chosen to describe the multitude of hybrid structures in a larger context and thus make connections visible. 
What is the specific perspective of this article? First, the function of hybridizations and hybrid structures is explained on the basis of systems theory. Second, it follows from the systems theory perspective that the following considerations can be assigned to the socalled either-or-logic, which excludes mixtures. Thirdly, the present discussion is largely based on Germanspeaking authors, because questions of hybridization and de-differentiation have been the subject of intensive discussion in German-language communication research in recent years. The fourth distinctive feature is that hybridization is described for PR starting in Section 4. This seems to make sense, because a large number of hybrid structures have emerged in PR, among others, vis-à-vis journalism, advertising and entertainment.

\section{Literature Review}

Hybridization and hybrid forms have experienced a real boom in research in recent years (Battilana et al., 2017, p. 131). In social science analyses, there are two opposing paradigms: the either-or-logic and the as-well-aslogic (Beck \& Grande, 2004, p. 51; Kron \& Berger, 2015, p. 7). The as-well-as-logic is primarily interested in mergers (Beck \& Grande, 2004, p. 51; Kron \& Berger, 2015, p. 7). This paradigm includes, for example, the actornetwork theory of Latour (1986, 1996; Czarniawska \& Hernes, 2005) and Parsons' interpenetration zones (Parsons, 1959). The as-well-as-logic usually assumes that the process of hybridization has led to the emergence of something new, which can then be described as a hybrid system or hybrid practice.

This article focuses on the either-or-logic (Figure 1). The either-or-logic adheres to differences between two systems or practices. Therefore, the hybridization concept is usually at the center of the either-or-logic. Hybridization is generally understood as a process in which something is adopted based on specific requirements. Thus, Boyer (1998) distinguishes it from diffusion, in which, for example, an innovation is adopted in a dominant manner:

Hybridization occurs when firms attempt to make principles or models drawn from one social and economic space compatible with the constraints and opportunities of another. This is a dynamic process which can eventually result in new forms of organi- zation and, potentially, new productive models. The concept of hybridization facilitates the exploration of the space between 'one best way' theories of scientific management and contingency or 'societal effect' theories. Hybridization may simply be local and transitory adoptions to special conditions. But even such adoptions may cumulate in wholly unforeseen ways to become new systems. (Tolliday et al., 1998, p. 6)

In a similar way, neo-institutionalism addresses hybridization in the context of the translation of managerial ideas. Similar concepts include recombination, editing and accretion. Hybridization emphasizes the performative role of those who produce, diffuse and adopt such institutional ideas and models (Fredriksson et al., 2013, p. 190; Hedmo et al., 2006). Either-or-logic also incorporates Niklas Luhmann's system theory, which will be the chosen perspective of this article and is discussed in more detail in the next Section.

The literature on hybrid forms and processes of hybridization can be systematized as follows: the literature on (a) hybridizations between different forms of strategic communication (e.g., PR and advertising), and (b) between strategic communication and publicity. Hybridizations between different forms of strategic communication have been described in greater depth for several years now. On the one hand, this has to be observed in the context of digitization: If users cannot assign online offers to different fields such as marketing, human resources or investor relations or-in the case of critics-do not want to, painstakingly established organizational structures of strategic communication may come under pressure (Mangold \& Faulds, 2009). Social media newsrooms can be interpreted as a reaction to these hybrid users (Zerfass \& Schramm, 2014). On the other hand, the hybrid nature of corporate social responsibility reports has been explained as follows:

[Corporate social responsibility], as a generic construct in its hybrid form, seems a 'typification' of three interdiscourses-discourses of promotion, goodwill, and self-justification-sociopragmatically co-constructed within an interdiscursive space. The purity of this genre lies in its hybridization, primarily in the integration of promotional cues in reporting genre, illustrating how interdiscursivity can explore the interrelationship between discursive and
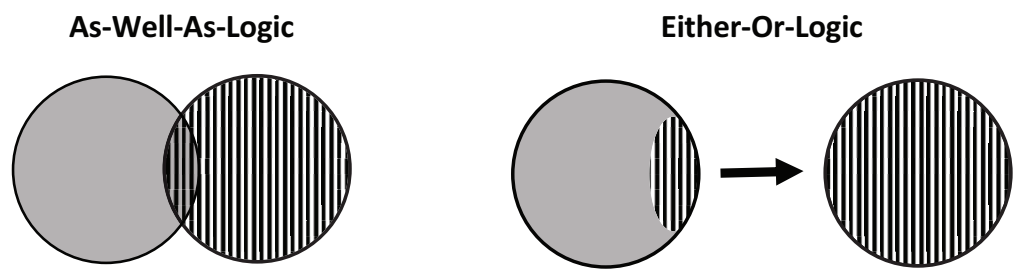

Figure 1. The as-well-as-logic and the either-or-logic. Source: Adapted from Kron and Berger (2015, p. 7) and Beck and Grande (2004, p. 51). 
professional practices. The limitation of the study was the limited choice of countries and sample size. (Bhatia, 2012, p. 221)

Hybrid forms and processes of hybridization between strategic communication and other forms, such as publicity, have been discussed more intensively. Since the 1990s, there has been talk of "hybrid messages" (Balasubramanian, 1994, p. 30) at the boundary between journalism and advertising. The hybrid character here aims at not recognizing the paid or strategic character when hybrid messages are defined as:

All paid attempts to influence audiences for commercial benefit using communications that project a noncommercial character; under these circumstances, audiences are likely to be unaware of the commercial influence attempt and/or to process the content of such communications differently than they process commercial messages. (Balasubramanian, 1994, p. 30)

Examples of hybrid advertising formats are, in addition to product placement, masked-art such as sculptures, songs, literature and images that present products but do not have an obvious commercial character (Balasubramanian, 1994). Hybrid formats intermingle with their environments by adopting the external features of other communicative genres and by obliterating contextual clues (Matteo \& Zotto, 2015). In the context of these hybrid advertising formats, the advantage or function of hybridity has also been explicitly explained: "Mimicry strategies offer marketeers the advantage of higher efficiency due to greater effectiveness" (Borchers, 2016, p. 201). With the advent of content marketing, the products of which appear more similar to journalistic products and, indeed, compete with them the debate has gained new importance (Taiminen et al., 2015; Zeng, 2018).

While hybridization in hybrid advertising formats was investigated from the perspective of advertising, it has been investigated in the relations between media and politics, including political PR, from the perspective of media and journalism (e.g., Hoffmann, 2003). The theory-oriented publications on hybridization and de-differentiation in journalism research (Görke, 2009; Loosen, 2015; in general: Görke \& Scholl, 2006) can also be included. Early examples of hybrid journalism included infotainment, edutainment, emotainment, confrontainment, advertainment, computainment or reality TV (Weischenberg, 2001, p. 69). These studies provide an important starting point for the considerations presented in this article.

\section{Hybridization and Hybrid Structures: A Theoretical Framework}

When the function of hybridizations and hybrid structures are elaborated in the following, the specific per- spective has to be stated. Firstly, the following considerations are based on the systems theory of the German sociologist Niklas Luhmann $(1995,2006)$, which is the third school of the "communication constitutes organization" perspective (Cooren et al., 2011; Schoeneborn, 2011) and has garnered growing attention in international strategic communication research in recent years (Blaschke, 2015; Holmström, 2005; Seidl, 2018). The central basic assumption of systems theory is that social systems are non-trivial systems that are self-referential closed and autopoietic (Luhmann, 1995). From the system theoretical perspective, therefore, it follows that the following considerations can be assigned to the either-or-logic. Thirdly, the authors are largely German-speaking, because questions of hybridization and de-differentiation have been discussed intensively in German-language communication research in recent years. The fourth characteristic is to be found in the fact that hybridization is described from the perspective of PR starting in Section 4.

One central advantage of the either-or-logic is identified in the articles on hybridizations, which often do not clearly state the two systems being hybridized. However, it is not possible to describe changes or even something completely 'new' if the (initial) systems have not been determined beforehand. Therefore, Section 4 explains the systems that hybridize. Among other things, the function and the binary code with which functional systems differentiate themselves from their environment must be mentioned (Luhmann, 1995). While the function designates which social problem a social system exclusively deals with, the binary code is the distinction with which a social system observes the environment. Thus, the function of science is to expand knowledge and it operates with the code true vs. untrue. Since in systems theory everything counts as part of a system or its environment, mixing zones or interpenetration zones à la Parsons are not conceivable.

While the function and code of a functional system are stable, systems continuously change their structures. Therefore, hybridizations are located below the functional and code level at the structural and program level. In business, scientific progress is observed with a view to future product innovations; journalism observes politics in search of current events. Hybridization means more than this observation of the environment: In hybridization, a system adopts program structures that are alien to that system (Görke, 2009, p. 84). One example of this is entertainment journalism, in which journalism adopts practices of the entertainment system.

Like mediatization (Mazzoleni \& Schulz, 1999), hybridization can be understood both as a process and as a description of a state. Hybridization as a process means that a system has adopted external program structures over a period of time. The state description 'hybridized' describes the extent of hybridization (Zucker, 1983) in a general way, following neo-institutionalist considerations. Specifically, we can speak of a hybridized system 
according to Schneider (2000, p. 183), if one system with its program structures refers decisively to another system without violating its own autopoietic mode of operation. Finally, hybrid structures are external structures that a system has adopted.

What problems do hybridizations solve, what is their function? Social systems tend to stick to proven structures, which was what Luhmann (1971) described as praise of routine. As much as such redundant structures are suitable for reducing complexity, they may also lead to problems if the system observes that they invariably lead to disappointment in the environment. Hybrid structures can help here. Since disappointments of the environment are observed primarily at the system periphery, hybridization is usually more likely to be observed at the periphery than at the system core. While the system core can remain unchanged, the system periphery can react to perceived problems by adopting external program structures (Görke, 2009). Hybridization as a strategy thus assumes an innovative function in systems and enables learning. Consequently, hybridizations strengthen the evolutionary ability of systems, but at the same time represent challenges by the system periphery to the core, in that they require it to reflect identity (Görke, 2009). To put it more bluntly: The periphery raises the question of whether it will be the new system core in the future-or whether it will remain a (temporary) marginal phenomenon.

Although all these changes take place merely at the structural level of a system and do not affect its function and code, the question of the risks of hybridization presents itself. Strong adoption of external program structures can lead to a "creeping loss of identity" (Marcinkowski, 1993, p. 228). From there, it is but a small step to de-differentiation. In the end, a hybridization process can "lead to the paradox that a system loses its specific function when it connects with another system" (Schneider, 2000, p. 186-187). A de-differentiation is present if there is actually a (partial or temporary) loss of function of a system-if, for example, journalism is integrated into the entertainment system. Gerhards (1991, p. 271) speaks of de-differentiation analogous to functional differentiation, when a "suspension of a permanently given system/environment distinction and its replacement by a new difference" is given. New forms of functional differentiation exist if, for example, hybridizations lead to the emergence of new systems or organizational subsystems. It becomes clear that the periphery with hybridizations can provoke the system core through too great a proximity to an environmental system and too great a distance to the system core.

\section{PR as a Result of a Hybridization Process}

Content marketing, corporate publishing, storytelling or brand PR: The practices behind these terms can be interpreted as examples of how media relations in particular adopts external structural elements. One could describe all these practices separately, which would result in an impressive variety of examples of hybridization. Instead, these practices will be presented in a wider context (Hoffjann, in press). First of all, the functional system of the public sphere is outlined, in which the differentiation of the PR itself can be understood as the result of a hybridization process. The differentiated PR service system makes unrestrained use of the program structures of journalism (Section 5.1), entertainment (Section 5.2) and advertising (Section 5.3).

PR have been deliberately chosen to explain hybridizations in strategic communication. On the one hand, $\mathrm{PR}$ is traditionally characterized by its close orientation towards journalism, as evidenced in the numerous journalistic practices constantly imitated in PR. On the other hand, current developments, such as the economic crisis facing journalism, or digitization, present new challenges for PR. The article explores how PR attempts to solve these problems by means of orientation towards entertainment and advertising.

Pursuant to Hoffjann and Arlt (2015), PR can be conceived of as one of several service systems in the public sphere. In the following, the functional system of the public sphere will first be outlined before showing how a process of hybridization has led to the differentiation of PR.

The social functional system of the public sphere enables society to observe itself, to orient itself and to synchronize itself momentarily (Görke, 1999; Marcinkowski, 1993). In the public sphere, as in other social functional systems, internal variations led to the emergence of service systems. Like Görke (2007), Hoffjann and Arlt (2015) identify four service systems: journalism, advertising, PR and entertainment. All four service systems publish collective messages. The central difference is found in the different programming of the code. This is the secondary code of the service systems. Journalism operates with the secondary code 'actuality'; entertainment with the secondary code 'pleasant experience'; for PR, the secondary code is 'convincing'; while for advertising it is 'seducing'.

Further relevant differences between the four service systems are highlighted by two additional distinctions. First comes the question of whether their public descriptions refer primarily to themselves or to others. Second, is the question of binding character. Journalism can be understood as binding external representation and entertainment as non-binding external representation. PR and advertising, on the other hand, serve the purpose of self-representation with the aim of influencing decisions in the interest of the positively described. While in advertising, as a non-binding self-representation, the fade-out rule is largely accepted (Schmidt, 2007), in the binding self-representation of PR it is normatively expected that the publications are factually appropriate. Accordingly, PR and advertising are oriented, for example, towards the presentation forms and aesthetics of their counterparts on the external 
representation side, i.e., PR to journalism and advertising to entertainment.

Binding PR is primarily assigned to instruments such as media relations, customer and employee magazines or most organizational content in social media; these are essentially the areas of owned and earned media (Xie et al., 2018, p. 168).

This is the identity of the differentiated PR service system. Looking at the emergence of PR, it becomes clear how differentiated systems can originate as hybrid structures. For PR work, this is to be located in Germany in the 19th century, when journalism was beginning to blossom, and the public began to observe organizations more and more critically (Bentele \& Wehmeier, 2003). The advertising that existed at that time (Zurstiege, 2011) quickly reached its limits with its non-binding nature, leading to the adoption of journalistic program structures. It was from these that the new PR service system subsequently emerged.

\section{Hybridization in PR}

Like any form of self-representation, PR suffers from the problems of a lack of trustworthiness, attention and relevance of its communication objects. In order to be able to continue to influence decisions in the interest of the positively described, PR unscrupulously adopts program structures of journalism, advertising and entertainment (Figure 2). If one views the aforementioned exam- ples in this context, it becomes clear to what extent some peripheral areas of PR have already hybridized. Conversely, hybridizations-e.g., of journalism versus PR, entertainment and advertising - could also be identified, thus making it clear that hybridizations are always a challenge for both sides (Görke, 2009, p. 79).

\subsection{Hybridization of $P R$ versus Journalism}

By orienting itself towards journalism, PR tries above all to solve its trustworthiness problems and the resulting problem of a lack of outreach. While (a) media relations aims to ensure that journalism transforms self-representations into more credible external representations or at least takes self-representations into account, (b) corporate publishing aims to bypass or replace journalism with quasi-journalistic content. For a long time, this orientation towards journalism and the adoption of journalistic structures were central to PR.

If one understands (a) media relations as attempts to steer towards the intermediate target group of journalists, it simulates journalistic selection criteria or modes of operation such as news factors and journalistic work routines in order to influence reporting in its own interests. In terms of systems theory, this can be conceived as external context steering vis-à-vis journalism, in which PR attempts to steer journalism by setting incentives (Willke, 1995). Thus, media relations can hardly be successful without hybrid structures, i.e., the adoption of

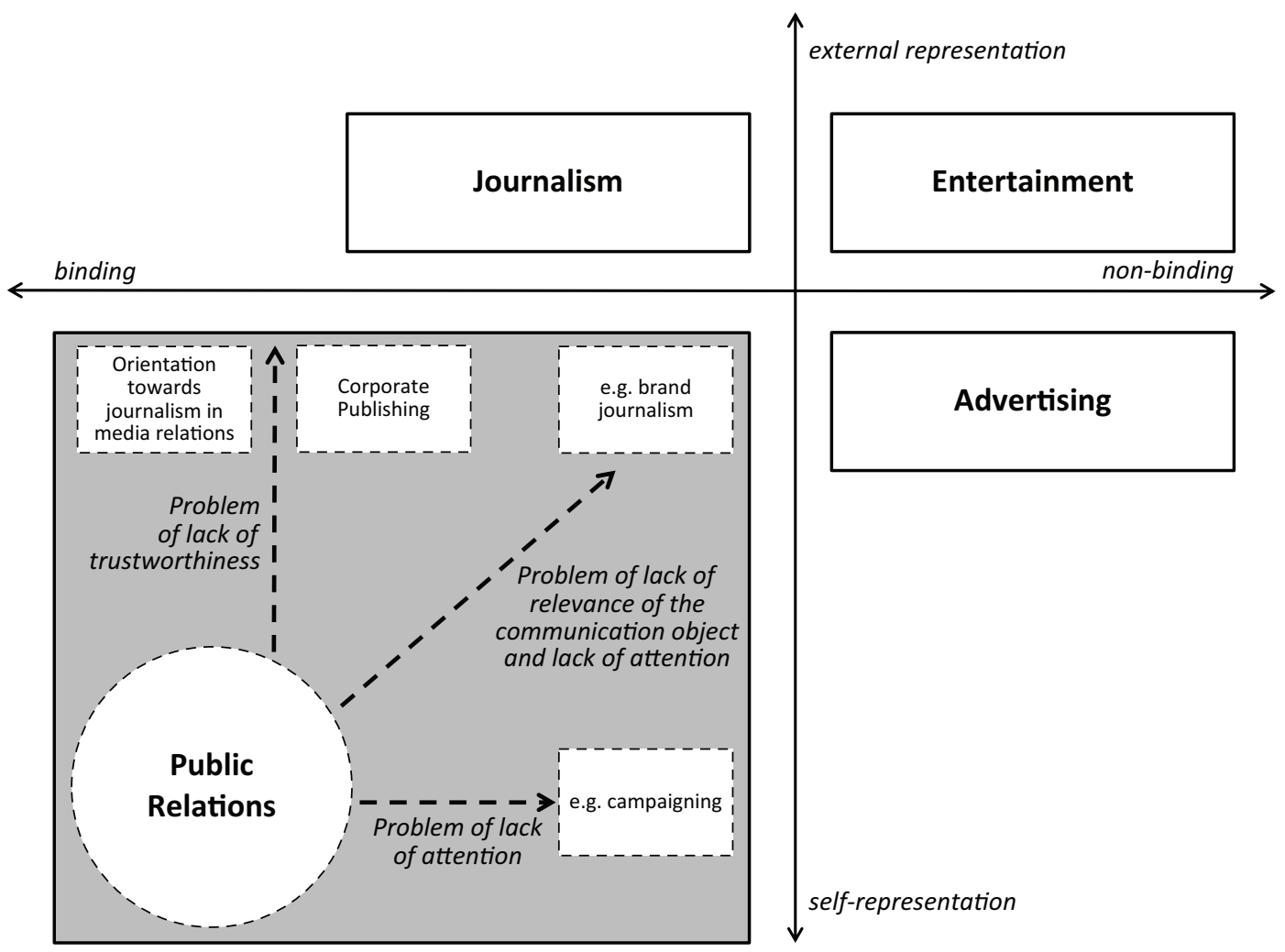

Figure 2. Hybridization of PR with other service systems in the public sphere. Source: Addapted from Hoffjann and Arlt (2015, p. 92). 
journalistic structures. This adoption of journalistic program structures can be deconstructed at all levels, while at the same time preserving functional autonomy.

The adoption of journalistic structures begins with concrete activities such as research and the selection of topics and facts. The decisive difference lies in the fact that all this is done under strategic aspects in PR. This applies equally to the content level, at which media relations instrumentalizes journalistic news factors (Schwarz, 2006). In all this, media relations' services can be limited to offering topics on which journalism is actively carrying out research (e.g., through invitations to press conferences). Especially in times of economic crisis in journalism, an alternative is being observed increasingly often: Media relations offers ready-produced articles that journalists can publish unedited, thus saving them resources. The various adoptions are continued in organizational structures. Although the hope of efficiency gains is central to the increasing adoption of newsroom concepts, press and media relations also expect a greater media presence.

A special aspect here is the personal level. In a functionally differentiated society, the assumption of roles is a self-evident part of all functional systems. However, due to inter-role conflicts (Obermaier \& Koch, 2015) it is viewed very critically when journalists are also active in PR. From a PR perspective, the advantage of so called 'PR-journalists' is that they are still anchored in journalism. Similarly, this applies to career-changers who switch from journalism to PR. The relatively high numbers who do this can be explained first and foremost by the hope that former journalists can simulate journalism more successfully.

In so-called (b) corporate publishing as part of content marketing, PR goes one step further than in media relations. The aim is no longer to influence journalism, but to bypass journalism by addressing target groups directly. For this purpose, binding selfrepresentations are disguised as binding external representations. Content marketing and specifically corporate publishing use journalism to attract the attention of their target groups. Pursuant to a communication research understanding, strategic communication simulates journalism and entertainment in content marketing. From a marketing research perspective, content marketing is the analysis, planning, execution and control of strategic communication activities (offline and online) that pursue their goal with relevant maintenance, information and service offers that the target group perceives, recommends or actively seeks. Content marketing is thus a typical example of hybridization between advertising and PR, as well as between journalism and entertainment. This process may ultimately result in large companies themselves becoming media houses with magazines, television channels and various web offerings (e.g., Red Bull).

In media relations, hybrid structures can increase the likelihood of their offerings being adopted or at least used by journalism. Particularly in times of declin- ing editorial budgets, the increasing professionalization of offers further improves publication opportunities. In corporate publishing, the adoption of journalistic structures also aims at mimicry in the sense of "hybrid messages" (Balasubramanian, 1994, p. 30), such that selfrepresentations are ultimately 'misunderstood' as representations by others, giving rise to journalistic follow-up communications (Görke, 2009).

\subsection{Hybridization of $P R$ Versus Entertainment}

PR suffers from a lack of relevance of the communication object and a lack of attention. It attempts to solve these problems by adopting the structures of entertainment. While the adoption of entertainment elements has always been a matter of course for advertising (Russel, 2007), this is also being seen increasingly often in PR. Similar to entertainment-oriented journalism (e.g., infotainment), this is intended to address additional audiences (e.g., Görke, 2009). In PR, entertainment orientation is particularly pronounced, e.g., in brand PR on consumer goods (Bull, 2013), when, for example, media presence is to be created with the help of celebrities or PR stunts. Storytelling (Gill, 2011; Kent, 2015), which is used to imbue brands with an emotionally charge, is also strongly represented in this area. The entertainment orientation is also reflected in the growing number of events and their increasingly elaborate staging-known as eventization.

On the one hand, PR has increasingly oriented itself towards entertainment in recent years; on the other hand, one particular risk of PR is evident here: Similar to journalism, too much focus on entertainment in PR has been linked with the risk of undermining the promise of bindingness.

\subsection{Hybridization of $P R$ Versus Advertising}

The competitive situation between organizations with their PR and advertising activities leads to a struggle for attention and a struggle for trustworthiness. Consequently, PR and advertising are constantly on the lookout for new attention-generating and trustworthiness-boosting strategies. It can be observed that PR and advertising use structural elements from the other side to solve these problems.

In principle, PR is concerned with differentiation from advertising since both differ in the aspect of (lacking) bindingness. A PR strategy that employs a large quantity of advertising elements would quickly lose trustworthiness. Thus, the described adoption of journalistic selection and construction criteria is precisely the attempt to be evaluated by journalists as appropriate and relevant. This orientation towards journalistic selection and construction criteria can, however, lead to PR restricting itself to such an extent that it no longer penetrates with its actual goals or messages-in other words, it no longer achieves attention for its strategic 
goals. Advertising elements or advertising itself can help to eliminate these attention deficits. PR primarily uses campaigns for this purpose. According to Wiencierz et al. (2015), campaigns can be understood as dramaturgybased, thematically limited and time-limited communicative strategies for generating public attention. Such campaigns have long been taken for granted in advertising because efficiency and effectiveness issues were raised at an early stage as a result of the high costs involved (e.g., Hallemann, 2008; Zielske, 1959). Accordingly, a precise target group approach, a focus on a product or a topic and, above all, the exact timing of the advertising circuit are all incorporated as a matter of course. With appropriate campaign planning, PR adopts a central structural element of advertising (Hoffjann \& Arlt, 2015 , p. 97). Attention problems may also lead an organization to decide that it can no longer achieve the necessary attention or reach using PR measures. Large classical advertising campaigns by associations can be interpreted as a response to this problem.

Conversely, the lack of binding character of advertising exacerbates the credibility problem in a special way. As much as advertising can enjoy the fool's freedom that nobody expects it to be true (Luhmann, 2000), it becomes difficult whenever it tries to do so. Since the 1970s, factual advertising has been observed as an alternative strategy to eliminate credibility deficits in advertising (Willems \& Kautt, 2003). Examples of this are advertisements in the form of management letters and advertorials, which at first glance are indistinguishable from editorial content and are only recognizable as advertising at second glance. These can be interpreted as advertising strategies aimed at adopting structural elements of PR.

\section{Conclusions}

PR has been described as the result of hybridization processes. Thus, PR is an example of how hybridization plays a central role in the process of differentiating social systems. However, the diversity and special relevance of hybridization has been worked out for the existing PR system.

This article focuses on PR because it has traditionally been oriented in a special way toward journalism and, in recent years, increasingly toward advertising and entertainment and has adopted their structures. Similarly, the theoretical framework could be used to describe hybridizations for the other service systems. Journalism takes over the campaign format from advertisingsimilar to PR: Campaign journalism attempts to dramaturgically build coverage of scoops over a longer period of time and is thus oriented toward advertising. The goal: to generate attention for an exclusive story. Journalism adopts elements of PR when it tries to emphasize its own performance strengths, e.g., by highlighting exclusive stories or its worldwide network of correspondents. By using such adoptions, editorial offices try to bind their readers, viewers and listeners. Finally, advertising traditionally orients itself to entertainment in order to solve the problem of the lack of relevance of the communication object. It tries to compensate the problem of a lack of credibility by taking its cue from journalism. It uses such hybrid advertising in an attempt to be perceived as publicity.

This highlights the advantage of locating hybridizations in the context of a theory of the public sphere: Each service system faces specific problems and attempts to solve these problems by adopting foreign structural elements. It can thus be used as a framework for future research projects. This would have the particular advantage that specific hybridization processes could be compared with each other and thus explored in context.

Hybrid structures provide an opportunity for learning and innovation as an adoption of external program structures. The system theoretical function of hybridization is to be found here, but is afforded little attention in current amendments: Hybridization makes it possible for social systems to try something new on the periphery without immediately surrendering their identity. Such a perspective focuses less on the threat of hybridand, thus, ambiguous - structures than on the effects on the ability of systems to change. Using the strategy of hybridization, PR remains capable of evolution (Görke, 2009, p. 86) and, in the face of a changing environment, can attempt to continue to influence decisions in the interest of the positively described. It is to be expected that the pressure to legitimate will continue to increase, as will the struggle for public attention. This will only further increase the need for hybrid structures, which is why it can be expected that we will see the emergence of growing numbers of hybrid structures in the future.

The question is whether such hybridizations lead to the emergence of new systems or, conversely, to the de-differentiation of existing systems. In PR, the boundaries between journalism and PR still seem to be relatively stable, because the value of largely independent information is evident, especially in core areas of journalism such as political news journalism. The situation is less clear on the journalistic periphery in topics such as fashion, beauty and travel, as the success of social media influencers with their sometimes nontransparent approach to the character of texts demonstrates. The boundary between binding PR and non-binding advertising seems to be coming under growing pressure due to phenomena such as fake news and bullshitting in political strategic communication. This raises the question of the extent to which the regular and, for the most part, openly displayed violation of the binding norm can lead to the de-differentiation or emergence of a new selfrepresentation service system.

\section{Conflict of Interests}

The author declares no conflict of interests. 


\section{References}

Balasubramanian, S. K. (1994). Beyond advertising and publicity: Hybrid messages and public policy issues. Journal of advertising, 23(4), 29-46.

Battilana, J., Besharov, M., \& Mitzinneck, B. (2017). On hybrids and hybrid organizing: A review and roadmap for future research. In R. Greenwood, C. Oliver, T. B. Lawrence, \& R. E. Meyer (Eds.), The Sage handbook of organizational institutionalism (2nd ed., pp. 133-169). Sage.

Beck, U., \& Grande, E. (2004). Das kosmopolitische Europa [Cosmopolitan Europe]. Suhrkamp.

Bentele, G., \& Wehmeier, S. (2003). From literary bureaus to a modern profession: The development and current structure of public relations in Germany. In K. Sriramesh \& D. Vercic (Eds.), The global public relations handbook: Theory, research and practice (pp. 199-221). Routledge.

Bhatia, A. (2012). The corporate social responsibility report: The hybridization of a "confused" genre (2007-2011). IEEE Transactions on Professional Communication, 55(3), 221-238.

Blaschke, S. (2015). It's all in the network: A Luhmannian perspective on agency. Management Communication Quarterly, 29(3), 463-468.

Borchers, N. S. (2016). Crossing the borders: A theory of hybrid advertising formats. In J. F. Hamilton, R. Bodle, \& E. Korin (Eds.), Explorations in critical studies of advertising (pp. 205-217). Routledge.

Boyer, R. (1998). Hybridization and models of production: Geography, history, and theory. In R. Boyer, E. Charron, U. Jürgens, \& S. Tolliday (Eds.), Between imitation and innovation: The transfer and hybridization of productive models in the international automobile industry (pp. 23-56). Oxford University Press.

Bull, A. (2013). Brand journalism. Routledge.

Cooren, F., Kuhn, T., Cornelissen, J. P., \& Clark, T. (2011). Communication, organizing and organization: An overview and introduction to the special issue. Organization Studies, 32(9), 1149-1170.

Czarniawska, B., \& Hernes, T. (2005). Actor-network theory and organizing. Liber.

Fredriksson, M., Pallas, J., \& Wehmeier, S. (2013). Public relations and neo-institutional theory. Public Relations Inquiry, 2(2), 183-203.

Gerhards, J. (1991). Funktionale Differenzierung der Gesellschaft und Prozesse der Entdifferenzierung [Functional differentiation of society and processes of de-differentiation]. In H. R. Fischer (Ed.), Autopoiesis: Eine Theorie im Brennpunkt der Kritik [Autopoiesis: A theory in the focus of criticism] (2nd ed., pp. 263-280). Carl-Auer-Systeme.

Gill, R. (2011). Corporate storytelling as an effective internal public relations strategy. International business and management, 3(1), 17-25.

Görke, A. (1999). Risikojournalismus und Risikogesellschaft [Risk journalism and risk society]. West- deutscher Verlag.

Görke, A. (2007). Perspektiven einer Systemtheorie öffentlicher Kommunikation [Perspectives of a system theory of public communication]. In C. Winter, A. Hepp, \& F. Krotz (Eds.), Theorien der Kommunikations-und Medienwissenschaft [Theories of communication and media studies] (pp. 173-191). Verlag für Sozialwissenschaften.

Görke, A. (2009). Untergang oder Neuschöpfung des Journalismus? [Decline or new creation of journalism?]. In B. Dernbach \& T. Quandt (Eds.), Spezialisierung im Journalismus [Specialization in Journalism] (pp. 73-93). VS Verlag für Sozialwissenschaften.

Görke, A., \& Scholl, A. (2006). Niklas Luhmann's theory of social systems and journalism research. Journalism Studies, 7(4), 644-655.

Hallemann, M. (2008). Advertising frequency and timing. In W. Donsbach (Ed.), The international encyclopedia of communication (pp. 1-5). Wiley.

Hedmo, T., Sahlin-Andersson, K., \& Wedlin, L. (2006). The emergence of a European regulatory field of management education. In M.-L. Salles-Djelic \& K. SahlinAndersson (Eds.), Transnational governance: Institutional dynamics of regulation (pp. 308-328). Cambridge University Press.

Hoffjann, O. (in press). Hybridisierung [Hybridization]. In P. Szyszka, R. Fröhlich, \& U. Röttger (Eds.), Handbuch der Public Relations [Handbook public relations] (4th ed.). Springer VS.

Hoffjann, O., \& Arlt, H. J. (2015). Die nächste Öffentlichkeit: Theorieentwurf und Szenarien [The next public sphere: theory design and scenarios]. SpringerVS.

Hoffmann, J. (2003). Inszenierung und Interpenetration: Das Zusammenspiel von Eliten aus Politik und Journalismus [Staging and interpenetration: The interplay of elites from politics and journalism]. Westdeutscher Verlag.

Holmström, S. (2005). Reframing public relations: The evolution of a reflective paradigm for organizational legitimization. Public Relations Review, 31(4), 497-504.

Kent, M. L. (2015). The power of storytelling in public relations: Introducing the 20 master plots. Public Relations Review, 41(4), 480-489.

Kron, T., \& Berger, P. (2015). Einleitung [Introduction]. In T. Kron (Ed.), Hybride Sozialität: soziale Hybridität [Hybrid sociality: Social hybridity] (pp. 7-16). Velbrück.

Latour, B. (1986). The powers of association. In J. Law (Ed.), Power, action and belief: A new sociology of knowledge? (pp. 264-280). Routledge and Kegan Paul.

Latour, B. (1996). Aramis or the love of technology. Harvard University Press.

Loosen, W. (2015). The notion of the "blurring boundaries" journalism as a (de-)differentiated phenomenon. Digital Journalism, 3(1), 68-84.

Luhmann, N. (1971). Lob der Routine [Praise of the rou- 
tine]. In N. Luhmann (Ed.), Politische Planung [Policy planning] (pp. 113-142). Westdeutscher Verlag.

Luhmann, N. (1995). Social systems. Stanford University Press.

Luhmann, N. (2000). The reality of the mass media. Stanford University Press.

Luhmann, N. (2006). System as difference. Organization, 13(1), 37-57.

Mangold, W. G., \& Faulds, D. J. (2009). Social media: The new hybrid element of the promotion mix. Business Horizons, 52(4), 357-365.

Marcinkowski, F. (1993). Publizistik als autopoietisches System: Politik und Massenmedien [Journalism as an autopoietic system: Politics and mass media]. Westdeutscher Verlag.

Matteo, S., \& Zotto, C. D. (2015). Native advertising, or how to stretch editorial to sponsored content within a transmedia branding era. In G. Siegert, K. Förster, S. M. Chan-Olmsted, \& M. Ots (Eds.), Handbook of media branding (pp. 169-185). Springer.

Mazzoleni, G., \& Schulz, W. (1999). "Mediatization" of politics: A challenge for democracy? Political Communication, 16(3), 247-261.

Obermaier, M., \& Koch, T. (2015). Mind the gap: Consequences of inter-role conflicts of freelance journalists with secondary employment in the field of PR. Journalism, 16(5), 615-629.

Parsons, T. (1959). An approach to psychological theory in terms of the theory of action. In S. Koch (Ed.), Psychology: A study of a science (pp. 612-711). McGraw-Hill.

Russell, C. A. (2007). Advertainment: Fusing advertising and entertainment. University of Michigan.

Schmidt, S. J. (2007). Modes of self-reference in advertising. In W. Nöth, \& N. Bishara (Eds.), Self-reference in the media (pp. pp. 47-60). Mouton de Gruyter.

Schneider, I. (2000). Hybridisierung als Signatur der Zeit [Hybridization as signature of time]. In C. Y. Robertson \& C. Winter (Eds.), Kulturwandel und Globalisierung [Cultural change and globalization] (pp. 175). Nomos.

Schoeneborn, D. (2011). Organization as communication: A Luhmannian perspective. Management Communication Quarterly, 25(4), 663-689.

Schwarz, A. (2006). The theory of newsworthiness applied to Mexico's press: How the news factors influence foreign news coverage in a transitional country. Communications, 31(1), 45-64.

Seidl, D. (2018). Organisational identity and selftransformation. Routledge.
Taiminen, K., Luoma-aho, V., \& Tolvanen, K. (2015). The transparent communicative organization and new hybrid forms of content. Public Relations Review, 41(5), 734-743.

Tolliday, S., Boyer, R., Charron, E., \& Jurgens, U. (1998). Introduction: Between imitation and innovationThe transfer and hybridization of productive models in the international automobile industry. In R. Boyer, E. Charron, U. Jürgens, \& S. Tolliday (Eds.), Between imitation and innovation. The transfer and hybridization of productive models in the international automobile industry (pp. 1-20). Oxford University Press.

Weischenberg, S. (2001). Das Ende einer Ära? Aktuelle Beobachtungen zum Studium des künftigen Journalismus [The end of an era? Current observations on the study of future journalism]. In H. J. Kleinsteuber (Ed.), Aktuelle Medientrends in den USA [Current media trends in the USA] (pp. 61-82). Westdeutscher Verlag.

Wiencierz, C., Pöppel, K. G., \& Röttger, U. (2015). Where does my money go? How online comments on a donation campaign influence the perceived trustworthiness of a nonprofit organization. International Journal of Strategic Communication, 9(2), 102-117.

Willems, H., \& Kautt, Y. (2003). Theatralität der Werbung [Theatricality of advertising]. Gruyter.

Willke, H. (1995). Systemtheorie III: Steuerungstheorie [Systems theory III: Steering theory]. Gustav Fischer.

Xie, Q., Neill, M. S., \& Schauster, E. (2018). Paid, earned, shared and owned media from the perspective of advertising and public relations agencies: Comparing China and the United States. International Journal of Strategic Communication, 12(2), 160-179.

Zeng, Y. (2018). Content marketing: Marriage of journalism with marketing and advocacy rings alarm bells. Media Asia, 45(1/2), 44-48.

Zerfass, A., \& Schramm, D. M. (2014). Social media newsrooms in public relations: A conceptual framework and corporate practices in three countries. Public Relations Review, 40(1), 79-91.

Zielske, H. A. (1959). The remembering and forgetting of advertising. Journal of Marketing, 23(3), 239-243.

Zucker, L. G. (1983). Organizations as institutions. In S. B. Bacharach (Ed.), Research in the sociology of organizations: A research annual (Vol. 2, pp. 1-47). JAI Press.

Zurstiege, G. (2011). The pragmatics of calling advertising art: Four systems theoretical approaches to art and advertising. Empedocles: European Journal for the Philosophy of Communication, 2(1), 3-17.

\section{About the Author}

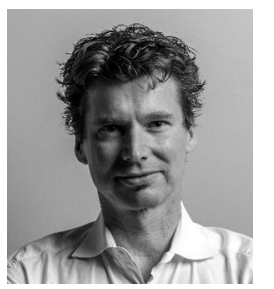

Olaf Hoffjann is Professor in the Department of Communication Studies at University of Bamberg, Germany. Hoffjann studied, inter alia, communication studies in Münster, Germany. From 2006 to 2019 he was Professor of Communication Management at the Mediadesign University for Applied Sciences in Berlin and of Media Management at the Ostfalia University for Applied Sciences in Salzgitter, Germany. He received his PhD for a system-theoretical study on relationship between PR and journalism. His research interests cover trust in PR, the reality of PR, and public affairs. 